\title{
Study of the influence of low concentrations of $\alpha$-zearalanol in feed on reproductive quality of hens
}

\author{
Shomina N. ${ }^{1}$, Kotyk A. ${ }^{2}$, Bondarenko A. ${ }^{3}$, Baidevliatova $0 .{ }^{4}$ \\ State poultry research station of NAAS \\ 20 Tsentralna Str., Birky, Zmiiv district, Kharkiv oblast, 63421, Ukraine \\ e-mail: 1shomina_n@ukr.net, 2amkotyk@ukr.net, ${ }^{3}$ bondarenkoangela2020@ukr.net, \\ ${ }^{4}$ baidevlatova o@ukr.net \\ ORCID: ${ }^{1}$ 0000-0001-9658-2559, 20000-0002-7221-4492, 30000-0002-6324-4577, 40000-0002-5316- \\ $184 X$
}

The purpose. To determine the effect of low concentrations of $\alpha$-zearalanol in feed on the reproductive qualities of laying hens. Methods. The study was conducted at the NAAS State poultry research station on hens, eggs, and incubation waste. At the age of 35 weeks, 2 groups (control and experimental) were formed from hens of Birkivska barvysta breed. The first 14 days (age of the herd $35-36$ weeks) birds received standard feed according to age needs. For the next 3 weeks, the birds of the experimental group received compound feed with an admixture of $\alpha$-zearalanol in the amount of $50 \mathrm{mkg} / \mathrm{kg}$ (bird age $37-39$ weeks), while hens and cocks of the control group received standard feed at that period. Poultry safety, egg weight, hatchability of eggs, distribution of waste by incubation periods were assessed. Results. The preservation of the bird during the experiment was $100 \%$. The positive effect of the additive on the weight of eggs in the experimental group of birds was revealed. Evaluation of the results of incubation of eggs of the experimental group in comparison with the control indicates a beneficial effect of adding $\alpha$-zearalanol to feed. Thus, if before the introduction of the additive the hatchability of eggs in the experimental group was $7.6 \%, 10.3$, and $12.4 \%$ lower than the control, then after the introduction - exceeded the control by 0.1 and $4.0 \%$. The increase in egg hatchability was due to the reduction of embryo death in the late stages of incubation, as well as the category of waste «frozen» and «dead». Conclusions. The stimulating effect of $\alpha$-zearalanol at a concentration of $50 \mathrm{mkg} / \mathrm{kg}$ on the reproductive qualities of poultry was revealed. Before the introduction of $\alpha$-zearalanol in the feed, the hatchability of eggs of the experimental group was $7.6 \%, 10.3$, and $12.4 \%$ lower than the control, after the introduction - the hatchability of the experimental group exceeded the control by 0.1 and $4.0 \%$. The reduction of embryo death in the late stages of incubation under the influence of $\alpha$-zearalanol deserves an in-depth study and has significant theoretical and practical significance.

Key words: poultry, feeding, additive, preservation, egg mass, egg hatchability, egg fertilization, incubation waste.

$$
\text { DOI: https://doi.org/10.31073/agrovisnyk202011-05 }
$$

The diversity of mycotoxins and their producers, the interaction of their pathological effects with each other and with other environmental factors, the search for optimal ways to interact with the risks they pose, determine a wide range of issues that need to be studied.

In total, more than 200 species of fungi producing mycotoxins are known. These fungi belong mainly to the genera Aspergillus, Penicillum, Fusarium, Claviceps and Alternaria, which are able to produce several hundred types of mycotoxins. Representatives of the genera Fusarium and Claviceps are characteristic of field conditions, and Aspergillus and Penicillum are also characteristic of storage [1, 2].

However, only a few of them are traditionally considered to pose the greatest global threat to human and domestic health: aflatoxins, ochratoxins, trichothecenes, fumonisins, zearalenone, and patulin [3-6]. The special danger of these mycotoxins is due to the rare combination of their prevalence, toxicity and resistance. They have been the cause of numerous cases of acute and chronic poisoning of humans and animals [7], including recent [8-10], some of which can be in human serum for a long time and excreted in breast milk [11-14]. In most countries of the world, maximum permissible level have been established only for the content of the above mycotoxins of "global importance" [15]. The overall prevalence of grain contamination with these mycotoxins is quite significant: modern analytical tools have detected their presence in more than half of the studied samples, although in most cases the content of mycotoxins did not exceed the maximum permissible level [16-18]. Meanwhile, much less known cases of poisoning by other mycotoxins, or contamination of feed or food raw materials. In addition, certain mycotoxins lose their importance for livestock due to the introduction of modern agronomic and hygienic measures (alkaloids of Claviceps, citreviridine).

Fungi of the genus Fusarium are producers of trichothecenes $A$ and B (T-2 and HT-2 toxins, diacetoxyscirpenol, vomitoxin), fumonisins, zearalenone are common contaminants of cereals in temperate regions, while Aspergillus and Penicillum producing aflatoxins, ochratoxins, citrinin, that are more characteristic of tropical and subtropical regions. In addition, the bird is relatively resistant to common 
mycotoxins such as zearalenone [19], fumonisin [20,21] or vomitoxin [22]. For example, a bird can tolerate concentrations of vomitoxin in feed up to $20 \mathrm{mg} / \mathrm{kg}$, while a concentration of $1-2 \mathrm{mg} / \mathrm{kg}$ already causes toxicosis in pigs. The reason is the low bioavailability of these mycotoxins and their rapid metabolism in birds [23].

Zearalenone is known as one of the most common contaminants in grain and feed. In European countries, according to generalized data, zearalenone was found in every fourth sample of corn and wheat, as well as in barley (19\%), oats (15\%) and feed (12\%); average levels from 2 to $300 \mu \mathrm{g} / \mathrm{kg}$ [24]. In the period 1982-1992 in the southwestern regions of Germany from 20 to $37 \%$ of oat samples were contaminated with zearalenone in concentrations of $0.08-0.244 \mathrm{mg} / \mathrm{kg}$ [25]. It was also reported that other fusariotoxins from the LRC group were detected in grain, in particular, contamination of corn and oats with zearalenol [26, 27].

Studies conducted in Ukraine show that zearalenone toxicosis is a common mycotoxicosis among farm animals, and is characterized by the development of hypertrophic processes in the tissues of the genital tract, increased ovarian and uterine mass, enlarged mammary glands and external genitalia, vulvovaginitis and other diseases [28]. The biological activity of zearalenone and related metabolites against mammals and poultry is based on their competitive binding to tarragon cytoplasmic receptors and induction of protein synthesis [29].

The main producers of zearalenone are the phytopathogen of cereals Fusarium graminearum Schwabe and Fusarium tricinctum.

Significant changes in the assessment of zearalenone as a factor in feed contamination led to the results of studying the impact on productive and reproductive qualities of chickens related to zearalenone compound $\alpha$-zearanol (zeranol), which is a metabolite of some species of Fusarium [30]. In a number of countries (USA, Canada, etc.) $\alpha$-zearalanol is produced industrially and is widely used in the fattening of cattle and sheep to increase weight gain and improve feed use.

Until the early 1990s, information on the effects of $\alpha$-zearalanol on birds was limited to a few publications. Thus, the authors reported a significant increase in weight gain in turkeys during the first 4 weeks after withdrawal when implanting $\alpha$-zearalanol in doses of $3000,6000,12000 \mu \mathrm{g}$ or when feeding in amounts of $10000-100000 \mu \mathrm{g} / \mathrm{kg}$ of feed. Turkeys receiving $\alpha$-zearalanol were also found to have a 50 -fold increase in oviduct and a decrease in ovarian and testicular weight. Implantation of $\alpha$-zearalanol in ducklings at doses of 3000-24000 $\mu \mathrm{g} / \mathrm{head}$ did not cause any significant deviations, except for a marked increase in the mass of the fallopian tube [31]. In studies by other authors after implantation of $\alpha$-zearalanol in turkeys 13-16 weeks of age at a dose of $12,000 \mathrm{mcg}$, no anabolic effect was found [32].

The results of research conducted at the Institute of Poultry UAAS showed that $\alpha$-zearalanol has the ability to affect the reproductive qualities of poultry. It was found that the inclusion of $\alpha$-zearalanol in feed in low concentrations does not adversely affect the weight of eggs and hatched chickens, and reduces embryo death in the second half of incubation [33, 34].

Given that zearalenone is a common factor in feed contamination, as well as data on the effects of low concentrations of $\alpha$-zearalanol on the reproductive quality of poultry, it is important to deepen research on the effects of zearalenone and related compounds in low concentrations on both reproductive and embryonic development. Therefore, the aim of this work was to establish the effect of low concentrations of $\alpha$-zearalanol in feed on the reproductive qualities of laying hens.

Material and methods of research. The study was conducted in the experimental farm "Preservation of the state gene pool of poultry", Department of Breeding, Technology and Innovation Management, Laboratory of Feed Quality Assurance at State Poultry Research Station of NAAS on chickens, eggs and incubation waste. At the age of 35 weeks, 2 groups (control and experimental) were formed from Birkivska barvista breeds. There were 53 hens and 8 roosters in the control group, in the experimental -55 hens and 8 roosters. The duration of the period of egg collection from these groups of birds was 5 weeks. The first 14 days (age of the flock 35-36 weeks) the bird received standard feed according to age needs. For the next three weeks, the birds of the experimental group received compound feed with an admixture of $\alpha$ zearalanol in the amount of $50 \mu \mathrm{g} / \mathrm{kg}$ (age of the bird 37-39 weeks), chickens and roosters of the control group and then received standard feed. Eggs were set for incubation every week during the experimental period. Incubation of eggs was performed in modernized laboratory incubators ILB-0.5 according to standard modes [35]. At the end of the incubation, its results were evaluated and analyzed, and the incubation waste was dissected to establish the category and causes of embryo death [36]. The obtained data were subjected to statistical analysis using the office program Exel.

Accounting indicators: preservation of poultry (\%), egg weight $(\mathrm{g})$, fertilization and hatchability of eggs (\%), death of embryos by incubation periods (\%), hatching of chicks (\%).

Results and their discussion. Preservation of the bird during the experiment was $100 \%$. As for the effect of $\alpha$-zearalanol in feed on egg weight, during the study period there was an increase in egg weight in the experimental group by 1.4-2.1 g, while in the control group the growth of this indicator was $0.3-0.5 \mathrm{~g}$ with the subsequent decrease to indicators which were at the age of 35-36 weeks (Table 1). 


\section{Mass of eggs of control and experimental groups of poultry}

\begin{tabular}{|l|c|c|c|c|c|c|}
\hline \multirow{2}{*}{ Group } & \multicolumn{5}{|c|}{ Вік птиці, тижнів } \\
\cline { 2 - 7 } & 35 & 36 & $37^{1}$ & 38 & 39 & 40 \\
\hline Experimental & $51,9 \pm 0,3^{\mathrm{a}}$ & $52,9 \pm 0,4$ & $53,2 \pm 0,5$ & $54,0 \pm 0,5^{\mathrm{b}}$ & $53,8 \pm 0,5^{\mathrm{b}}$ & $53,3 \pm 0,5$ \\
\hline Control & $53,7 \pm 0,6$ & $53,5 \pm 0,4$ & $54,0 \pm 0,4$ & $53,4 \pm 0,4$ & $53,7 \pm 0,5$ & $53,4 \pm 0,5$ \\
\hline
\end{tabular}
group

${ }^{1}$ Beginning of feeding compound feed with an admixture of $\alpha$-zearalanol to poultry of the experimental

The results of incubation of eggs collected during the study period are shown in table 2 . There was an improvement in both fertilization and hatchability of eggs from the experimental group of birds after the introduction of the impurity (see Table 2).

\section{The results of incubation of eggs collected during the study period}

\begin{tabular}{|c|c|c|c|c|c|c|c|c|c|c|c|c|}
\hline \multirow[t]{2}{*}{ Group } & \multirow{2}{*}{$\begin{array}{c}\text { Set } \\
\text { eggs, } \\
\text { pcs }\end{array}$} & \multirow{2}{*}{$\begin{array}{l}\text { Hatchability } \\
\text { of fertile } \\
\text { eggs, } \%\end{array}$} & \multicolumn{2}{|c|}{$\begin{array}{l}\text { Hatchability of } \\
\text { set eggs, \% }\end{array}$} & \multicolumn{2}{|c|}{$\begin{array}{l}\text { Unfertilized } \\
\text { eggs }\end{array}$} & \multicolumn{2}{|c|}{$\begin{array}{l}\text { «Кров'яне } \\
\text { кільце» }\end{array}$} & \multicolumn{2}{|c|}{ Завмерлі } & \multicolumn{2}{|c|}{$\begin{array}{l}\text { Задох- } \\
\text { лики }\end{array}$} \\
\hline & & & pcs & $\%$ & pcs & $\%$ & pcs & $\%$ & pcs & $\%$ & pcs & $\%$ \\
\hline \multicolumn{13}{|c|}{ The first batch of eggs ( 1 week of egg collecting) } \\
\hline Experimer & 48 & $81,0 \pm 4,9^{a}$ & 34 & 70,8 & 6 & 12,5 & 3 & 6,3 & 1 & 2,1 & 4 & 8,3 \\
\hline Control & 101 & & 86 & 85,1 & 4 & 3,9 & 3 & 3,0 & 3 & 3,0 & 5 & 5,0 \\
\hline \multicolumn{13}{|c|}{ The second batch of eggs ( 2 week of egg collecting) } \\
\hline Experimental & 86 & $77,3 \pm 4,8^{a}$ & 58 & 67,4 & 11 & 12,8 & 5 & 5,8 & 4 & 4,7 & 8 & 9,3 \\
\hline Control & 117 & $87,6 \pm 3,1$ & 99 & 84,6 & 4 & 3,4 & 3 & 2,6 & 2 & 1,7 & 9 & 7,7 \\
\hline \multicolumn{13}{|c|}{ The third batch of eggs ( 3 week of egg collecting), beginning of feeding with zeranol) } \\
\hline Experime & 84 & $76,0 \pm 4,9^{a}$ & 57 & 67,9 & 9 & 10,7 & 5 & 5,9 & 5 & 5,9 & 8 & 9,6 \\
\hline Control & 117 & $88,4 \pm 3,0$ & 99 & 84,6 & 5 & 4,3 & 4 & 3,4 & 3 & 2,6 & 6 & 5,1 \\
\hline \multicolumn{13}{|c|}{ The fourth batch of eggs ( 4 week of egg collecting) } \\
\hline Experime & 79 & $88,9 \pm 3,7$ & 64 & 81,0 & 7 & 8,9 & 3 & 3,8 & 0 & 0 & $\checkmark$ & 6,3 \\
\hline Control & 89 & $88,8 \pm 3,3$ & 79 & 88,8 & 0 & 0 & 2 & 2,2 & 2 & 2,2 & 6 & 6,8 \\
\hline \multicolumn{13}{|c|}{ The fifth batch of eggs (5 week of egg collecting) } \\
\hline Experime & 77 & $91,5 \pm 3,3^{b}$ & 65 & 84,4 & 6 & 7,8 & 1 & 1,3 & 2 & 2,6 & 3 & 3,9 \\
\hline Control & 57 & $87,5 \pm 4,4$ & 49 & 86,0 & 1 & 1,8 & 1 & 1,8 & 1 & 1,8 & 5 & 8,6 \\
\hline
\end{tabular}

After feeding compound feed with zeranol, hatchability and fertilization of eggs of the experimental group increased by an average of $12.1 \%$ and $3.6 \%$, respectively (compared to the period when the bird received standard feed). The increase in egg hatchability was due to the reduction of embryo death in the late stages of incubation, the categories of waste "frozen" and "dead" (see Table 2).

The results of incubation of eggs of the experimental group in comparison with the control also indicate a favorable effect of inclusion in the feed of zeranol: if before the introduction of the impurity hatchability of eggs of the experimental group was $7.6 \%, 10.3 \%$ and $12.4 \%$ lower than control, then after the introduction - the excretability of the experimental group exceeded the control by 0.1 and $4 \%$.

At the opening of the incubation waste, performed for each batch of eggs, no syndromes characteristic of embryotoxicosis were detected.

Thus, in our experiments, the addition of $\alpha$-zearalanol to feed had a stimulating effect on the reproductive performance of poultry. There is no doubt that obtaining such results requires further conduct and deepening of research in this area.

\section{Conclusions}

The stimulating effect of $\alpha$-zearalanol at a concentration of $50 \mu / \mathrm{kg}$ on the reproductive parameters of poultry was revealed. Before the introduction of $\alpha$-zearalanol in the feed, the hatchability of eggs of the experimental group was $7.6 \%, 10.3 \%$ and $12.4 \%$ lower than the control, after the introduction - the hatchability of the experimental group exceeded the control by 0.1 and $4.0 \%$. The reduction of embryo death in the late stages of incubation under the influence of $\alpha$-zearalanol deserves in-depth study as one that has significant theoretical and practical significance. 


\section{References}

1. Fungi, producing significant mycotoxins. (2012). IARC Scientific publications, 158, 1-30.

2. Ismaiel, A.A., \& Papenbrock, J. (2015). Mycotoxins: producing fungi and mechanisms of phytotoxicity. Agriculture, 5, 492-537. doi: 10.3390/agriculture5030492

3. Bhat, R.V., Shetty, P.H., \& Amruth, R.P. (1997). A foodborne disease outbreak due to the consumption of moldy sorghum and maize. Journal of toxicology: clinical toxicology, 35(3), 249-255. doi: 10.3109/15563659709001208

4. Pitt, J.I. (2000). Toxigenic fungi: which are important? Medical mycology, 38(1), 17-22. doi: 10.1080/mmy.38.s1.17.22?journalCode=immy20

5. Richard, J.L. (2007). Some major mycotoxins and their mycotoxicoses. International Journal of food mycroiology, 119(1-2), 3-10. doi: 10.1016/j.ijfoodmicro.2007.07.019

6. Milicevic, D., Lakicevic, B., Petronijevic, R., Petrovic, Z., Jovanovic, J., Stefanovic, S., \& Jankovic, S. (2019). Climate change: impact on mycotoxines incidence and food safaty. Theory and practice of meat processing, 4, 1, 9-16.

7. Selected mycotoxins: ochratoxins, trichotecenes, ergot. (1990) Environmental health criteria №105. World health organization. Geneva.

8. Bhat, R., Ral, R.V., \& Karim, A.A. (2010). Mycotoxins in food and feed: present status and future concerns. Comprehensive reviews in food science and food safety, 9, 57-81. doi: 10.1111/j.15414337.2009.00094.x

9. Janovic, M., Trailovic, D., Kukoli, V., et al. (2015). An outbreak of fumonisin toxicosis in horses in Serbia. World mycotoxin Journal, 8(4), 387-391. doi: 10.3920/WMJ2014.1812

10. Probst, C., Njapau, H., \& Cotty, P. J. (2007) Outbreak of an Acute aflatoxicosis in Kenya: identification of the causal agent. Applied and environmental microbiology, 73(8), 2762-2764. doi: 10.1128/AEM.02370-06

11. Chen, C., Wang, L., Lu S., You, S, Zhang, Y., Wang, L., \& Santella, R. (2010). Elevated aflatoxin exposure and increased risk of hepatocellular carcinoma. Hepatology, 24(1), 38-42. doi: 10.1002/hep.510240108

12. Coronel, M.B., Sanchis, V., Ramos, A.J., \& Marin, S. (2010). Review. Ochratoxin A: Presence in human plasma and intake estimation. Food Science and technology International, doi: $10.1177 / 1082013209353359$

13. Jonsyn, F.E., Maxwell, S.M., \& Hendrickse, R.G. (1995). Ochratoxin A and aflatoxins in breast milk samples from Sierra Leone. Mycopathologia, 131(2), 121-126. doi: 10.1007/BF01102890

14. Radic, B., Fuchs, R., Peraica, M., \& Lucić A. (1997). Ochratoxin A in human sera in the area with endemic nephropathy in Croatia. Toxicology letters, 91(2), 105-109. doi: 10.1016/S03784274(97)03877-0

15. Worldwide regulations for mycotoxins in food and feed in 2003. (2004). FAO. URL: www.fao.org/docrep/007/y5499e/y5499e00.htm

16. Monbaliu, S., Van Poucke, C., Detavernier, C., et al. (2010). Occurrence of mycotoxins in feed as analyzed by LC-MS/MS method. Journal of agricultural and food chemistry, 58(1), 66-71. doi: $10.1021 / \mathrm{jf} 903859 \mathrm{z}$

17. Shatzmayr, G., \& Streit, E. (2013). Global occurrence of mycotoxins in the food and feed chain: facts and figures. World mycotoxin journal, 6(3), 213-222. doi: 10.3920/WMJ2013.1572

18. Kos, J., Hajnal, E.J., Malachová, et al. (2020). Mycotoxins in maize harvested in Republic of Serbia in the period 2012-2015. Part 1: Regulated mycotoxins and its derivatives. Food Chemistry, 312, 126034. doi: 10.1016/j.foodchem.2019.126034

19. Allen, N.K., Mirocha, C.J., Weaver, G., Aakhus-Allen, S., \& Bates, F. (1980) Effects of dietary zearalenone on finishing broiler chickens and young turkey poults. Poultry science, 60(1), 124-131. doi: $10.3382 / p s .0600124$

20. Kubena, L.F., Edrington, T.S., Camps-Holtzappel, C. , Harvey, R.B.,Elissalde, M.H., Rottinghaus, G.E. (1995). Influence of fumonisine present in Fusarium moniliforme culture material, and T-2 toxin on turkey poults. Poultry science, 74(2), 306-313. doi: 10.3382/ps.0740306

21. Knutsen, H., Alexander, J., Barregård, L., et al. (2018). Risks for animal health related to the presence of fumonisins, their modified forms and hidden forms in feed. EFSA Journal, 16, 5. doi: 10.2903/j.efsa.2018.5242

22. Pestka J.J. (2007). Deoxynivalenol: Toxicity, mechanisms and animal health risks. Animal feed science and technology, 137, 283-298. doi: 10.1016/j.anifeedsci.2007.06.006

23. Devreese, M., De Backer, P., \& Croubels, S. (2013). Overwiew of the most important mycotoxins for the pig and poultry husbandry. Vlaams Diergeneeskundig Tijdschrift, 82, 171-180.

24. Gareis, M., Bauer, J., Enders, C., \& Gedek, B. (1987, Sept.). Contamination of cerealsand feed with Fusarium mycotoxins in European countries. Fusarium: Mycotoxins Taxon a. Path.: Semin. Warsaw, 441-472.

25. Muller, H.M., Reimann, J., Schumacher, U., \& Schwadorf, K. (1998). Natural occurrence of Fusarium toxines in oats harvested during five years in an area of southwest Germany. Food Addit. Contam, 15(7), 801-806. doi: 10.1080/02652039809374713 
26. Chang, H.L., \& de Vries, J.W. (1984). Short liquid chromatographic method for the determination of zearalenon and alfa-zearalenol. J.A.O.A.C., $67,741$.

27. Mirocha, C.J., Schauerhamer, B., Christensen, C.M., Niku-Paavola, M.L., \& Nummi, M. (1979). Incidence of zearalenol in animal feed. Appl. Environmenti. Microbiol, 38, 749.

28. Trufanova, V.O., Bratishko, N.I., Kotyk, A.M., Sakhatskyi, I.M., \& Novozhytska, Yu.M. (2005). Mikotoksykozy ptytsi: etiolohiia, diahnostyka, profilaktychni zasoby i metody [Mycotoxicosis of birds: etiology, diagnosis, preventive measures and methods]. Kharkiv, 67-85. [in Ukrainian].

29. Lindsay, D.G. (1985). Zeranol - a nature-identical oestrogen. Fd. Chem. Toxic, 23(8), 767-774. doi: 10.1016/0278-6915(85)90273-X

30. Richardson, K.E., Hagler, W.M., \& Mirocha, C.J. (1985). Production of zearalenone, alfa- and betazearalenol, and alfa- and beta- zearalanol by Fusarium spp. in rice culture. Journal of Agricultural and food chemistry, 33(5), 862-866. doi: 10.1021/jf00065a024

31. Wentworth, B.C., Mashalay, M., Birrencott, G., Zimmerman, N., \& Wineland, M.J. (1979). The performance of growing turkeys and ducks implanted and fed zeranol. Poultry Science, 58(4), 1122.

32. Castado, D.J., Jones, J.E., \& Maurice, D.V. (1993). Growth and carcass composition of femaile turkeys implanted with anabolic agents and fed high protein and low protein diets. Archives of Animal Nutrition. Berlin, 40, 8, 703-712. doi: 10.1080/17450399009428419

33. Kotyk, A. M., Trufanova, V.O., Bratishko, N.I., \& Stefanovych, O. M. (1998). Diia zearalenonu na vidtvorni yakosti ta biokhimichni pokaznyky kurei [The effect of zearalenone on reproductive qualities and biochemical parameters of chickens]. Bulletin of Agricultural Science, 5, 33-36.

34. Kotik, A.M., Trufanova, V.A., Stefanovich, A.N., Bratishko, N.I., \& Gella, I.M. (1994, 15-16 September). Vliyanie razlichnykh kontsentratsiy zeranola na produktivnye kachestva myasnykh tsyplyat [The effect of different concentrations of zeranol on the productive qualities of meat chickens]. (pp. 59-60). 2nd Baltic Poultry conference Proceedings. Vilnius.

35. Breslavets, V.O., Shomina, N.V., Artemenko, O.B., \& Baidevliatova, O.M. (2018). Inkubatsiia yaiets silskohospodarskoi ptytsi [Incubation of poultry eggs]. Toolkit. [in Russian].

36. Djadichkina, L.F., Pozdnjakova, N.S., Glavatskih, O.V. et al. (2004). Rukovodstvo po biologicheskomu kontrolyu pri inkubatsii selskokhozyaystvennoy ptitsy [Guidelines for biological control during incubation of poultry eggs]. Guidelines. Sergiev-posad [in Russian]. 